\title{
LIVING STANDARDS IN BLACK AND WHITE: EVIDENCE FROM THE HEIGHTS OF OHIO PRISON INMATES, 1829 - 1913
}

\author{
SCOTT ALAN CARSON \\ THOMAS N. MALONEY
}

CESIFO WORKING PAPER NO. 1775

CATEgORY 4: LABOUR MARKETS

August 2006

An electronic version of the paper may be downloaded

- from the SSRN website:

- from the RePEc website:

wWw.SSRN.com

- from the CESifo website:

www.RePEc.org

www.CESifo-group.de 


\title{
LIVING STANDARDS IN BLACK AND WHITE: EVIDENCE FROM THE HEIGHTS OF OHIO PRISON INMATES, 1829 - 1913
}

\begin{abstract}
The use of height data to measure living standards is now a well-established method in the economic history literature. Moreover, a number of core findings in this literature are widely agreed upon. There are still some populations, places, and times, however, for which anthropometric evidence remains thin. One example is African-Americans in the Northern US in the 1800s. Here, we use new data from the state prison in Ohio to track heights of black and white men from 1829 to 1913. We corroborate the well-known mid-century height decline among white men in Ohio, found by Steckel and Haurin (1994) using National Guard data. We find that black men in Ohio were shorter than white men, throughout the century and controlling for a number of characteristics. We also find a pattern of height decline in midcentury similar to that found for white men.
\end{abstract}

JEL Code: I12, I31, I32, J15, N31.

\author{
Scott Alan Carson \\ School of Business \\ University of Texas, Permian Basin \\ 4901 East University \\ Odessa, TX 79762 \\ USA \\ Carson_S@utpb.edu
}

\author{
Thomas N. Maloney \\ Department of Economics \\ University of Utah \\ 1645 Campus Center Dr., Rm 308 \\ Salt Lake City, UT 84112 \\ USA \\ maloney@economics.utah.edu
}

Please do not cite without permission from the authors.

We appreciate comments from participants from the Western Economic Association, Western Social Science Association, and the Center for Economic Studies at the University of Munich. Comments from Marco Sünder and John Komlos were particularly helpful. Owen WallaceServera and Anita Voorhies provided excellent research assistance. All errors remain those of the authors. 
Industrialization and modernization bring about rising incomes, wages and life expectancy in the long run (Komlos 1987; Floud, Wachter and Gregory 1990, pp. $272-$ 273). However, in the short run they also create economic and social turmoil, such as increasing inequality and more virulent disease environments, which can lead to deteriorating biological living conditions. Hence, the overall effect of the early stages of industrialization and modernization on biological living standards depends on which of these effects dominates. A growing body of evidence indicates that the net effect was negative for free Northern whites in the US in the early stages of industrialization. In the second quarter of the $19^{\text {th }}$ century, the average stature of males began a sustained diminution that may not have ended until the $4^{\text {th }}$ quarter of the $19^{\text {th }}$ century (Komlos, 1987, 1996).

While the rough outlines of this pattern are established, a full understanding of the details requires additional evidence. In particular, little is known about the biological living standards of Africa-Americans in the North at this time. In this paper, we use a new data set collected from the records of the Ohio state prison in Columbus to compare 
the development of the biological living standards of black men and white men in Ohio through the $19^{\text {th }}$ century. This is a very appropriate time and place in which to study the biological living standards of males in a rapidly developing economy. During the early $19^{\text {th }}$ century, states such as Ohio, Illinois and Indiana were America's far western frontier. By the mid- $19^{\text {th }}$ century, these states were beginning to develop an industrial sector. By the end of the $19^{\text {th }}$ century, the Great Lakes region contained substantial manufacturing centers but also areas that remained, to a large degree, rural.

In addition, our data are unusually well suited for constructing racial comparisons in the North. While existing studies of African-American biological living standards tend to rely on race-specific documents, including slave records and identification cards issued to free blacks in the South, we have large samples of both black and white individuals from a uniform set of records from the Ohio state prison. Our data set also covers an unusually long time period, allowing us to examine developments both before and after the Civil War. Using these data, we examine the following questions: First, how did biological living conditions vary across demographic, geographic, and socioeconomic categories for men in Ohio? Second, how large were stature differences between blacks and whites and what were their sources? Finally, did blacks in Ohio experience the same kind of stature cycle that whites experienced?

\section{The Biological Living Standards of African-Americans in the 1800s}

There is a substantial literature on the biological living standards of blacks under slavery. Black slaves reached adult heights well below those of whites, and slave children experienced profound height and health deficits (Steckel 1986). The fact that 
slaves did not achieve mean heights equal to those of free whites is not very shocking. However, tracking the time path of black heights in the South does reveal some surprises. Komlos and Coclanis (1997) document increasing average stature for black convicts in Georgia in the antebellum period, and Steckel (1995) finds a similar increase among transported slaves. This is in marked contrast to height reductions among whites in this period. One likely explanation for this difference is the change in the composition of the slave population in terms of nativity. As the proportion African-born declined among slaves, average heights increased due to better acclimation to the North American disease climate.

Evidence on free blacks in the $19^{\text {th }}$ century is also largely from the South and largely from the antebellum period. Bodenhorn (1999) studies registration records for free blacks in Virginia and finds a pattern that contrasts somewhat with the pattern observed among slaves. While free blacks were generally taller than slaves, their height declined between 1800 and 1830 (dating by birth cohorts), in contrast to increases in slave heights during this era. Using similar records for Maryland, Komlos (1992) documents a decline in the average heights of free blacks in that state between the 1820s and the 1840s. So free Southern blacks may have experienced a decline in average height in the antebellum period similar to that found for whites.

\section{Blacks in Ohio in the 1800s}

In this paper, we provide evidence on biological living standards for blacks and whites in one Northern state, Ohio. Ohio occupies a complex place in $19^{\text {th }}$ century African-American history. It was central to the operation of the underground railroad, 
the point at which tens of thousands of slaves emerged into freedom (Johnson and Campbell p. 36). At the same time, Ohio's antebellum legal restrictions on blacks, while "by no means unique,” were “certainly among the most severe” in the North (Gerber p. 9). Beginning in 1804, blacks in Ohio were required to obtain a "certificate of freedom" in order to live and work in the state, and beginning in 1807 they were required to post a \$500 bond with their county clerk within 20 days of arriving in the state, though the law was only sporadically enforced (Cayton, pp. 9, 110; Johnson and Campbell, p. 39). Black children were forbidden from attending public school in Ohio until the 1840s, and legally segregated schools predominated from the 1840s to the 1880s (Cayton, pp. 61, 200). Notably, though blacks of course gained access to the vote under the $15^{\text {th }}$ amendment in 1870, the explicit (but ineffectual) restriction of suffrage to whites remained in the Ohio state constitution until 1923 (Ibid., p. 231).

There was some variation within Ohio in the status of the black community. The southern part of the state generally placed the greatest limits, both explicit and implicit, on African-American life. This may have reflected anxieties about the potential influx of large numbers of blacks from Kentucky and Virginia, as well as close cultural and economic ties between Ohioans in this part of the state and residents of the South (Gerber, pp. 9-11). In the Northern part of the state, the (substantially smaller) black community enjoyed somewhat greater openness on the part of the white population. For instance, Cleveland began to subsidize local black schools in 1843 and abolished segregation in local schools in the 1850s (while the state did not pass a school desegregation law until 1887) (Cayton pp. 62-3, 200). 
The end of the Civil War brought considerable change in the size and circumstances of Ohio's black community. The black population of Ohio rose from 36,673 in 1860 to 63,213 in 1870 . Though blacks were still less than three percent of the population of the state, this increase was the fastest among all Northern states during this decade, leaving Ohio second to Pennsylvania in total black population and second to New Jersey in percent black among Northern states. The arrival of black refugees during the war initially provoked an "hysterical” response, including the passage of a miscegenation law in 1861. However, the fact that many of the wartime and post-war black migrants to Ohio moved as families and settled in rural areas may have dampened the reaction of whites somewhat (Gerber, pp. 28-33).

The pace of increase in Ohio’s black population slowed substantially over time: the 72 percent growth of the 1860s was followed by a 26 percent increase in the 1870 s and a nine percent increase in the 1880s. In 1870, half of all Ohio blacks were Southern born, but this share fell to 36 percent in 1900 as migration slowed (Ibid., pp. 28-41). Much of the growth of the black population was concentrated in the Southern and Western parts of the state. Where the black community was growing most rapidly, efforts to constrain the economic and political aspirations of that community were apparently most severe. This process is perhaps most visible in the contrast between racial political and economic patterns in Cleveland and in Cincinnati (Bertaux, pp. 1412). 


\section{$\underline{\text { Biological Living Standards in Ohio }}$}

Most research on heights in the $19^{\text {th }}$ century US places individuals in the Midwest in the middle of the height spectrum. People in the non-coastal South and in the West were taller, and people in the coastal South, the East, and the Northeast were on average shorter (Steckel 1992a, p. 289). Steckel and Haurin (1994, pp. 121-122) examine Ohiospecific evidence on heights using measurements of $19^{\text {th }}$ century Ohio National Guardsman. They find a modest decline of about 1 inch in average male stature between 1878 and 1896, with a post-1896 recovery. This may suggest that the stature decline observed in the antebellum period in more industrialized regions in the Eastern US began later in Ohio (Komlos, 1987). Steckel and Haurin also uncover a ranking of heights across occupations: professionals were the tallest, followed by farmers, clerical workers, and skilled and unskilled laborers. Native-born recruits were taller than foreign-born recruits by nearly 1 inch. Rural residents within Ohio were nearly 1 quarter inch taller than urban residents.

We are unaware of any published analysis of the stature of black Ohioans in the $19^{\text {th }}$ century. Still, the historical context provided above and the broader literature on biological living standards in this period suggest several points to keep in mind as we examine our data. First, region of birth may matter, both because heights in general varied across region and because the heights of slaves followed a different pattern over time than did the heights of free blacks. Second, region of residence within Ohio may matter, if blacks in the Southern part of the state faced greater obstacles to economic advancement. Finally, while we should expect urban and rural residents to have achieved 
different heights, we should keep in mind that cities in the Midwest were not as residentially segregated in the $19^{\text {th }}$ century as they would become during and after the Great Migration of blacks out of the South. As a result, black city residents and white city residents probably faced similar disease climates, with similar implications for their health and height (Taylor, 1993; Cuff, 2005, p. 19).

\section{The Ohio Prison Data}

The first Ohio penitentiary was established in 1815, and housed a prison population of 150 inmates in the first five years of operation. Shortly thereafter, a second prison was constructed near the first with an estimated 1,113,462 hours of convict labor. The site of the present Ohio State penitentiary, from which our records are extracted, was completed in 1834. The main inmate housing site had a capacity of 700 inmates and was modeled after the prison facility in Auburn, New York. In the Auburn, or "silent", correctional system, it was anticipated that inmates would be rehabilitated by being compelled to work, with the profits used to support the Ohio state prison.

Close proximity to other inmates and unsanitary conditions facilitated the spread of disease. Like the rest of America, inmates in the Ohio prison were stricken with cholera in 1849, and 121 out of 423 inmates succumbed to the disease (Rosenberg, pp. 101-120). Note, though, that our evidence on heights is not affected by these conditions because measurements were taken as inmates were received and therefore reflect their pre-incarceration living standards. 
It is against this historical backdrop that we examine nearly 36,000 male inmate records from the Ohio prison system between 1829 and 1913. ${ }^{1}$ Prison guards routinely recorded the dates inmates were received, age at incarceration, complexion, state of birth, stature, pre-incarceration occupation, the county in which the inmate was received and the inmate’s crime. "Race" was not recorded explicitly in the prison records but can be inferred from the detailed descriptions of “complexion” that are provided. ${ }^{2}$ Detailed descriptions of occupation are provided as well, but we focus here on the main distinction in the literature on biological living standards - that between farmers and non-farmers.

\section{The Heights of Ohio’s Black and White Prisoners}

Prison records are particularly useful for examining changes in biological living standards. They are widely available. They also provide among the most accurate stature measurements. ${ }^{3}$ While they are not random samples, the selectivity they represent is to some degree an advantage for the study of changes in stature. The individuals in these records were likely to be of low socioeconomic status and so were most vulnerable to

\footnotetext{
${ }^{1}$ Nearly all records between 1829 and 1913 are used here, except those for 1868, which were not available.

${ }^{2}$ Following Komlos and Coclanis (1996), we code as "black" all inmates with complexions recorded as black, brown, copper, dark brown, dark mulatto, ginger, light brown, light mulatto, mulatto and yellow. Inmates with complexions recorded as fair, florid, dark, light, ruddy, sallow, sandy and swarthy are considered as from European ancestry and are coded "white.”

${ }^{3}$ Many $19^{\text {th }}$ century and earlier stature measurements were rounded to the nearest inch or half inch. However, there was great care in recording inmate statures because accurate measurement may have had legal implications in the event that an inmate escaped and later was recaptured. Most inmates' statures were recorded at quarter, eighth, and even sixteenth increments.
} 
economic change. For the study of height as an indicator of change in biological living standards, this kind of selection is preferable to the kind of selection that marks many military records - minimum height requirements for service.

Table 1 presents average heights for white and black adult men (older than 22) in the prison sample, calculated separately for farmers and non-farmers, by region of birth, and by proximity to water (that is, residence prior to incarceration in a county containing or bordered by a river or large lake), for all birth cohorts combined. For both groups, the expected height patterns hold: farmers were taller than non-farmers, and individuals who lived near water were somewhat shorter than individuals who did not. Regional averages followed similar but not identical patterns for blacks and whites. For both groups, individuals born in the Middle Atlantic were shortest, those born in the West were relatively tall, and the Ohio-born fell near the middle of the ranking. Notably, though, Southeastern-born whites were taller than whites born anywhere else, while Southeastern-born blacks were relatively short. Though we can not directly identify former slaves in the data set, it seems likely that this height disadvantage for Southeastern-born blacks reflects the fact that many of these individuals grew up under the harsh biological conditions of slavery. Given the discussion in the narrative history of variation in black status within Ohio, especially the particularly severe limitations on black status in the southern part of the state, we calculate average heights separately for the two-county band along the state's southern border. Whites in these counties were slightly taller than whites in the rest of the state, while blacks were somewhat shorter. 
Within all cells, white heights exceeded black heights, with the gap for the Southeasternborn being quite large. 
Table 1: Mean Adult Height by Category (in Centimeters)

\begin{tabular}{|c|c|c|c|c|c|}
\hline & \multicolumn{2}{|c|}{ White } & \multicolumn{2}{|c|}{ Black } & \multirow{2}{*}{$\begin{array}{c}\text { Height } \\
\text { Difference }\end{array}$} \\
\hline & Height & $\mathrm{N}$ & Height & $\mathrm{N}$ & \\
\hline Farmer & 173.85 & 2872 & 172.09 & 370 & 1.76 \\
\hline Non-Farmer & 171.92 & 14465 & 170.50 & 3143 & 1.42 \\
\hline \multicolumn{6}{|l|}{ Region of Birth } \\
\hline New England & 172.11 & 610 & 171.18 & 32 & 0.93 \\
\hline Middle Atlantic & 171.58 & 4098 & 169.67 & 327 & 1.91 \\
\hline Great Lakes (exc. Ohio) & 171.75 & 1128 & 170.17 & 106 & 1.58 \\
\hline Ohio & 172.33 & 8913 & 170.89 & 983 & 1.44 \\
\hline Southeast & 173.46 & 2043 & 170.67 & 1860 & 2.79 \\
\hline Plains & 171.76 & 296 & 170.41 & 86 & 1.35 \\
\hline West & 173.08 & 249 & 171.89 & 120 & 1.19 \\
\hline \multicolumn{6}{|l|}{ Water } \\
\hline Lake & 171.21 & 2476 & 169.89 & 455 & 1.32 \\
\hline No Lake & 172.41 & 14861 & 170.78 & 3058 & 1.63 \\
\hline River & 172.15 & 3851 & 170.37 & 1071 & 1.78 \\
\hline No River & 172.28 & 12030 & 170.93 & 1849 & 1.35 \\
\hline Southern County & 172.42 & 4253 & 170.53 & 1188 & 1.89 \\
\hline Non-Southern County & 172.18 & 12814 & 170.73 & 2332 & 1.45 \\
\hline
\end{tabular}

Source: Source: Date used to study Ohio biological conditions is a subset of a much larger $19^{\text {th }}$ century prison sample. All available records from American state repositories have been acquired and entered into a master file. These records include Arizona, California, Colorado, Idaho, Illinois, Kansas, Kentucky, Missouri, New Mexico, Ohio, Oregon, Pennsylvania, Tennessee, Texas, Utah and Washington. Prison records used in this manuscript are from the Ohio prison.

Notes: Southern counties are those along the Ohio river, plus those immediately North of these border counties: Hamilton, Clermont, Brown, Adams, Scioto, Lawrence, Gallia, Meigs, Washington, Monroe, Belmont, Jefferson, and Columbiana, Butler, Carroll, Clinton, Guernsey, Harrison, Highland, Jackson, Morgan, Noble, Pike, Stark, Vinton, and Warren. Regions are defined as follows: New England = CT, ME, NH, RI, VT and "New England;" Middle Atlantic = DE, DC, MD, NJ, NY, and PA; Great Lakes = IL, IN, MI, and WI; Plains = IA, KS, MN, MO, NE ND, and SD; Southeast = AL, AR, FL, GA, KY, LA, MS, NC, SC, TN, VA, and WV; West = AZ, NM, OK, TX, AK, CA, ID, UT, CO, MT, NV, OR, WA, WY, and "Indian Territory." 
Figure 1: Mean Adult Height by Race and Year of Birth

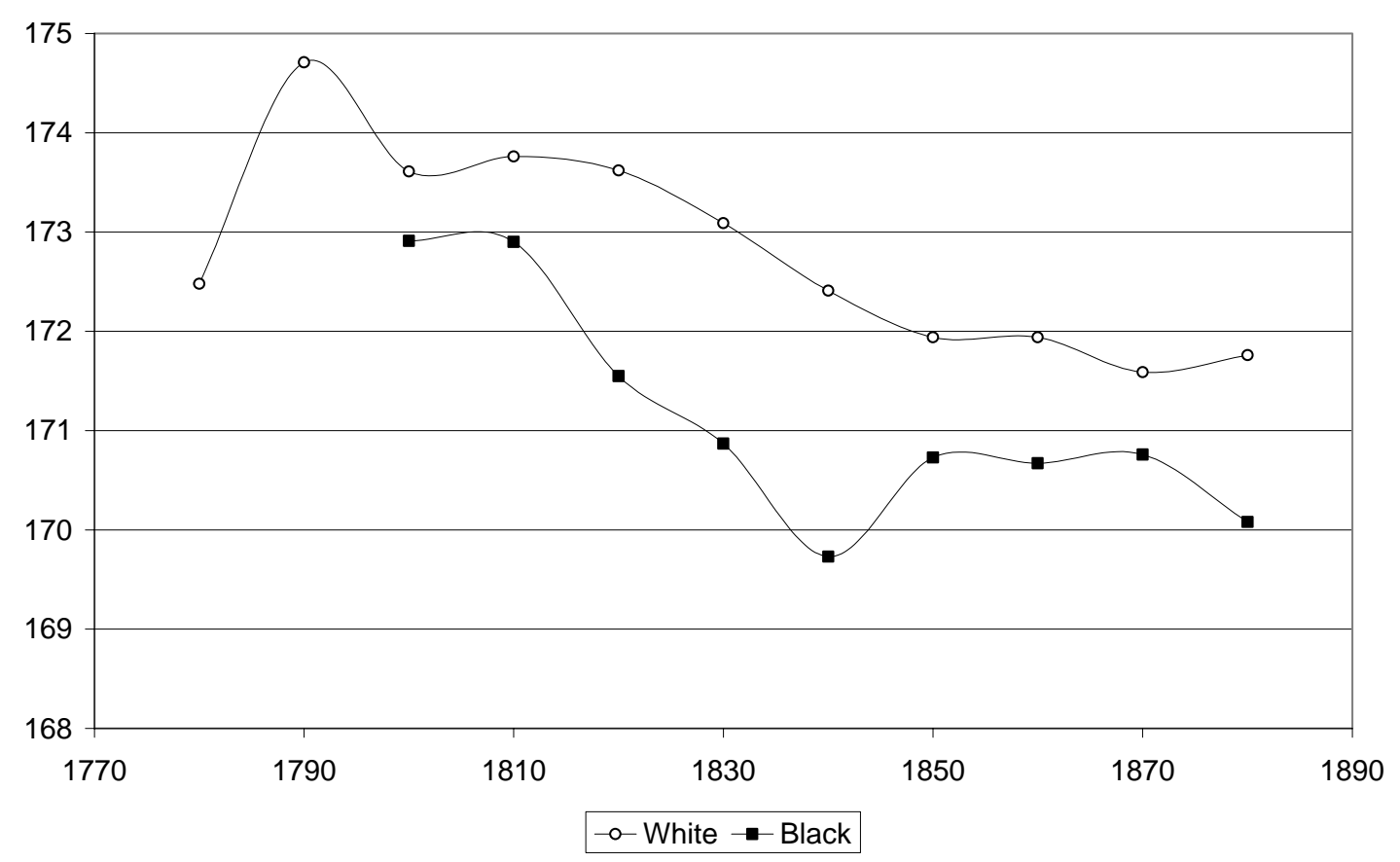

When we examine change in height over time, we find the pattern of decline in the mid-1800s which has been frequently demonstrated for whites. Our evidence shows that the heights of Northern-resident blacks also followed this time path (see Figure 1). We present height by year of birth and race, for adults, in Figure 1 . While the decline occurs for both blacks and whites, it is steeper for blacks through 1840, with some absolute and relative recovery for this group after that point. Comparing our white inmates to Steckel and Haurin’s Ohio National Guard sample indicates that our prisoners were shorter, and that height decline set in a bit earlier for our group. For Guardsmen born between 1840 and 1880, Steckel and Haurin find average heights of between 68.4 and 68.9 inches, or 173.74 to 175.01 centimeters, depending on location of residence, and 
their sample exhibits little net change in average height over this period (the decline in their sample comes later - see Steckel and Haurin, 1994, pp. 123-124). As noted above, we should not be surprised to find these kinds of differences between the National Guard sample and our prison sample. We expect individuals in prison samples to be short (due to both poorer average conditions and the absence of the minimum height requirements that characterize military samples). We also expect heights calculated from prison samples to exhibit greater sensitivity to fluctuations in living standards, so that deteriorating biological conditions might show up earlier in our prison sample than in the National Guard sample.

Regional differences in height, changes in migration patterns, and selectivity in migration might affect the picture painted in Figure 1. For example, the share of the white sample born in the Southeast fell from almost 20 percent in 1800 to about 8 percent in 1880. This change would probably lead to declining average heights among whites in our sample, all else equal. As an initial control for these kinds of compositional effects, we calculate the time path of height separately for the Ohio-born - see Figure 2. The general decline across birth cohorts is still apparent, as is the white height advantage in each decade. ${ }^{4}$ (In the regression analysis below, we will control for region of birth directly.)

\footnotetext{
${ }^{4}$ In all graphs, dates refer to the decade beginning in that year, and points are plotted only for cells containing at least 20 observations.
} 
Figure 2: Mean Adult Height by Race and Year of Birth, Ohio Born Inmates

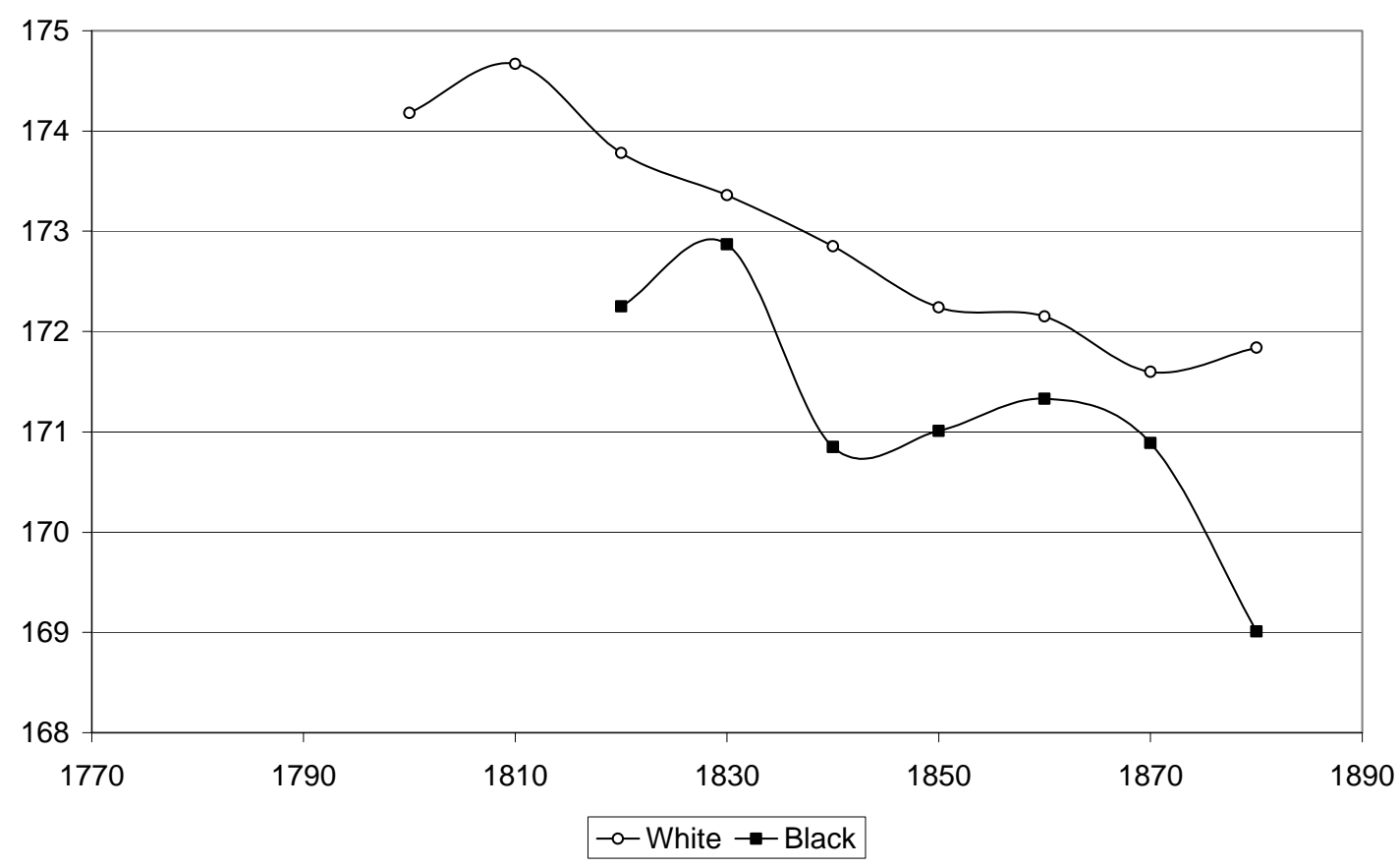

Comparing the heights of black youth and white youth is somewhat more complicated. Because there is substantial change in height with age during youth (ages 14 to 22 here), height averages constructed without age controls are not too informative. We therefore construct age-standardized height measures for youth as follows: we pool the sample across all birth years and calculate overall age-specific height means for whites. We then normalize the height of each individual by the white mean for the given age. Both the raw means (in centimeters) by age and race and the standardized means by characteristic are presented in Table 2. As for adults, individuals from the West tended to be tall, the Ohio-born held a position near the middle of the height rankings, and the black-white gap among the Southeastern-born was especially large. The patterns related 
to farming and proximity to water appear as expected. For youth, the racial gap within southern counties in Ohio did not exceed the gap within non-southern counties.

Table 2: Mean Youth Height by Category

\begin{tabular}{|c|c|c|c|c|c|}
\hline & \multicolumn{2}{|c|}{ White } & \multicolumn{2}{|c|}{ Black } & \multirow{2}{*}{$\begin{array}{c}\text { Height } \\
\text { Difference }\end{array}$} \\
\hline & Height & $\mathrm{N}$ & Height & $\mathrm{N}$ & \\
\hline \multicolumn{6}{|c|}{ A. By Age (centimeters) } \\
\hline 14 & 160.56 & 23 & 160.71 & 17 & -0.15 \\
\hline 15 & 164.20 & 80 & 164.87 & 25 & -0.67 \\
\hline 16 & 167.35 & 266 & 166.83 & 70 & 0.52 \\
\hline 17 & 169.47 & 646 & 167.68 & 144 & 1.79 \\
\hline 18 & 170.10 & 885 & 168.33 & 204 & 1.77 \\
\hline 19 & 171.45 & 1120 & 169.46 & 235 & 1.99 \\
\hline 20 & 171.26 & 1125 & 170.56 & 232 & 0.70 \\
\hline 21 & 172.10 & 1432 & 170.91 & 297 & 1.19 \\
\hline 22 & 172.00 & 1575 & 170.87 & 327 & 1.13 \\
\hline \multicolumn{6}{|c|}{ B. By Characteristics (Age Standardized) } \\
\hline Farmer & 100.92 & 1242 & 100.09 & 161 & 0.83 \\
\hline Non-Farmer & 99.81 & 5910 & 99.14 & 1390 & 0.67 \\
\hline \multicolumn{6}{|l|}{ Region of Birth } \\
\hline New England & 99.72 & 183 & 98.06 & 14 & 1.66 \\
\hline Middle Atlantic & 99.51 & 1410 & 99.05 & 111 & 0.46 \\
\hline Great Lakes (exc. Ohio) & 99.87 & 487 & 98.98 & 66 & 0.89 \\
\hline Ohio & 100.07 & 4196 & 99.31 & 651 & 0.76 \\
\hline Southeast & 100.79 & 630 & 99.13 & 615 & 1.66 \\
\hline Plains & 99.91 & 151 & 99.05 & 31 & 0.86 \\
\hline West & 100.36 & 95 & 100.58 & 63 & -0.22 \\
\hline \multicolumn{6}{|l|}{ Proximity to Water } \\
\hline Lake & 99.66 & 1051 & 98.86 & 133 & 0.8 \\
\hline No Lake & 100.06 & 6101 & 99.28 & 1418 & 0.78 \\
\hline River & 99.88 & 2159 & 99.16 & 696 & 0.72 \\
\hline No River & 100.05 & 4993 & 99.31 & 855 & 0.74 \\
\hline Southern County & 100.04 & 1868 & 99.30 & 542 & 0.74 \\
\hline Non-Southern County & 99.99 & 5284 & 99.21 & 1009 & 0.78 \\
\hline
\end{tabular}

Each individual's height is standardized by the average height for whites of the same age. See Table 1 for definition of regions and of southern counties.

Source: Ohio prison data set 
Figure 3: Mean Height of Youths by Age

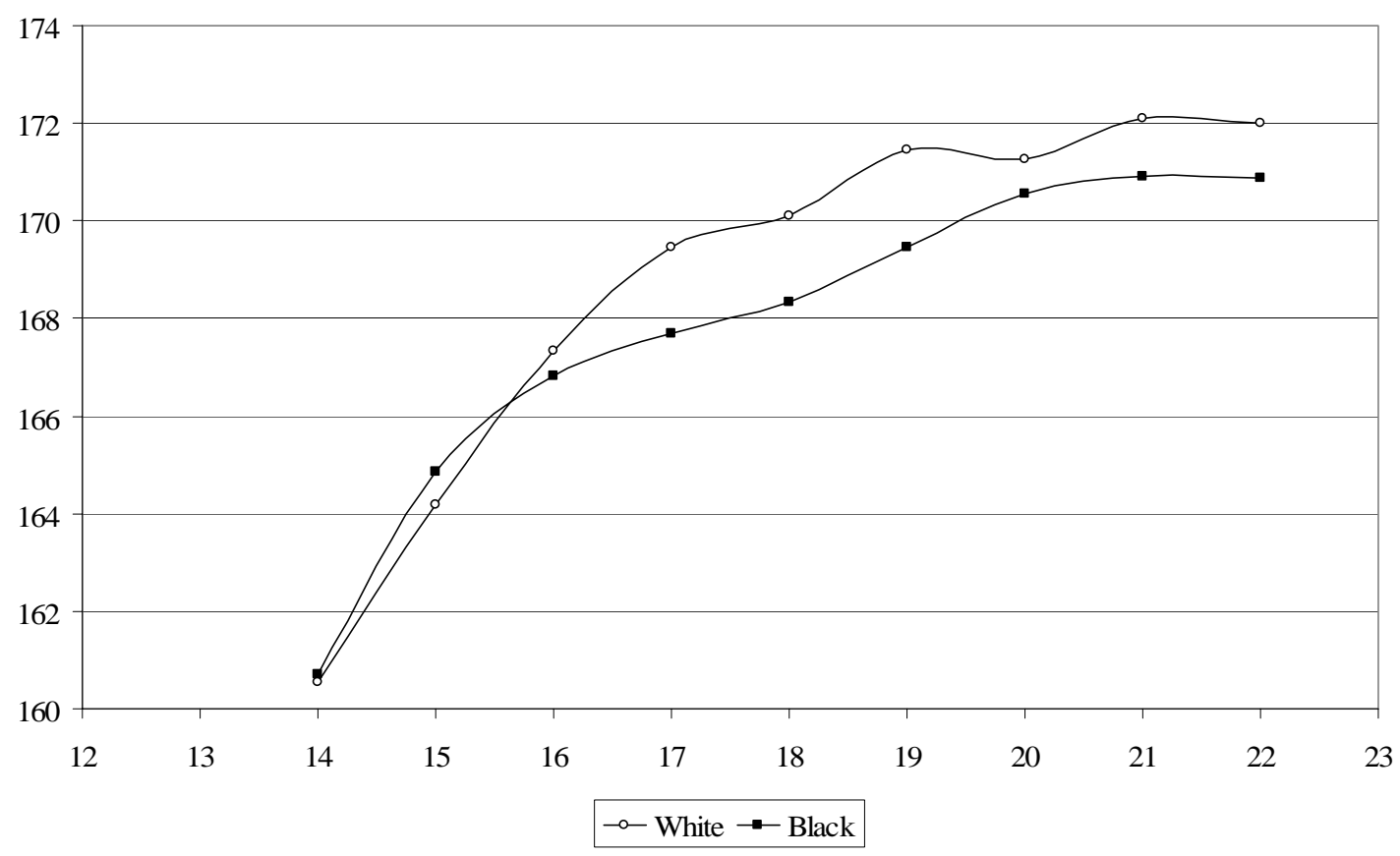

The pattern in height by age is itself worth noting. At ages 14 and 15, average black height exceeded average white height, but adolescent growth was much more rapid for young white men after that point. The growth process lasted somewhat longer for black youth, though, producing some net catch-up after age 19 (see Figure 3). This finding of shorter adult height but a longer growth process for more impoverished populations fits the patterns documented elsewhere (Cuff 2005, p. 16). 
Figure 4: Mean Standardized Youth Height by Race and Year of Birth

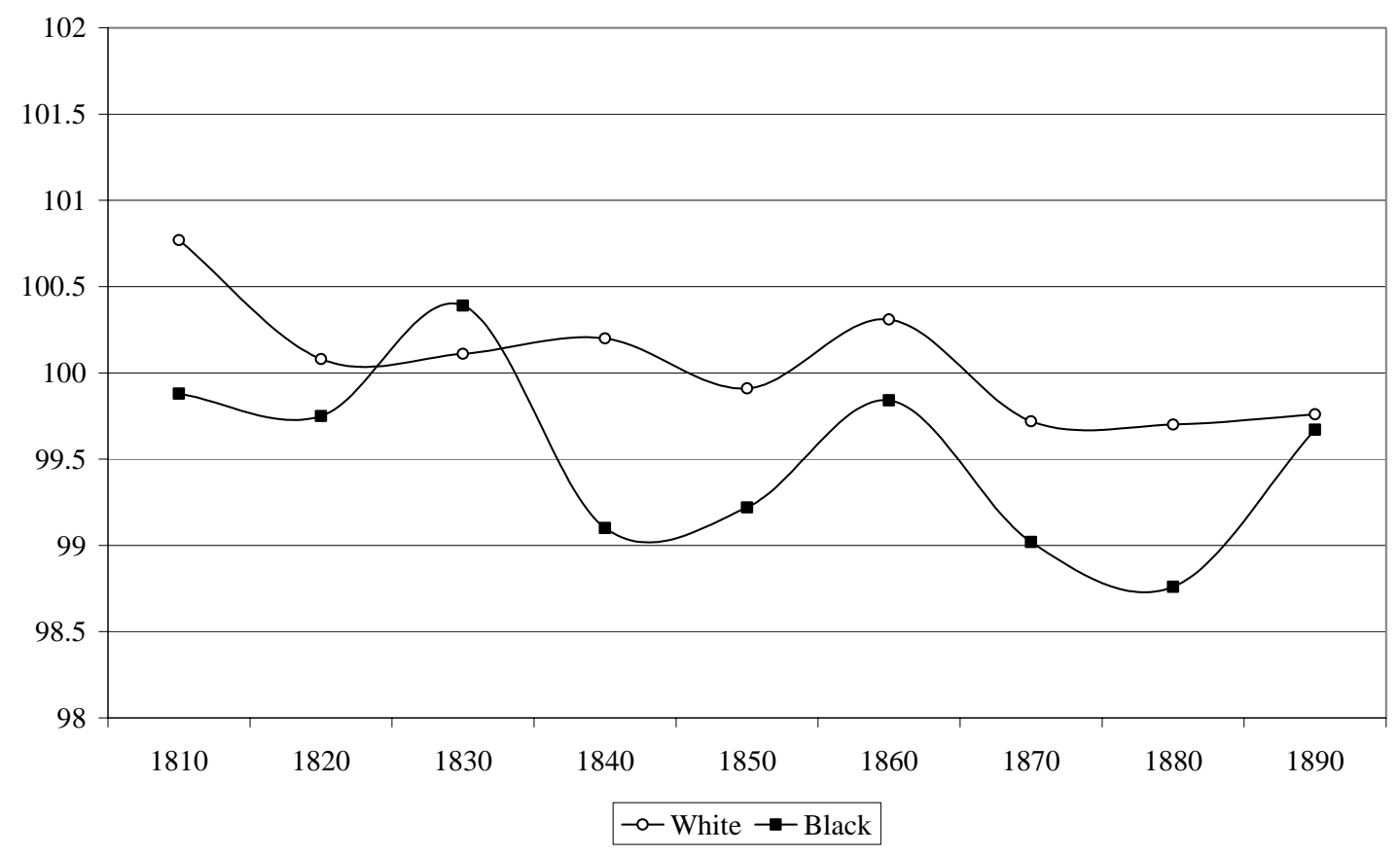

Change over time in the standardized height of youths appears somewhat muted (see Figure 4). Controlling for region of birth by restricting the sample to the Ohio-born produces a more dramatic sense of decline over time for both blacks and whites (Figure 5). White youth heights exceed black youth heights in all cases, except for the 1830s cohort in the all-region sample. 
Figure 5: Mean Standardized Youth Height By Race and Year of Birth, Ohio-Born Inmates

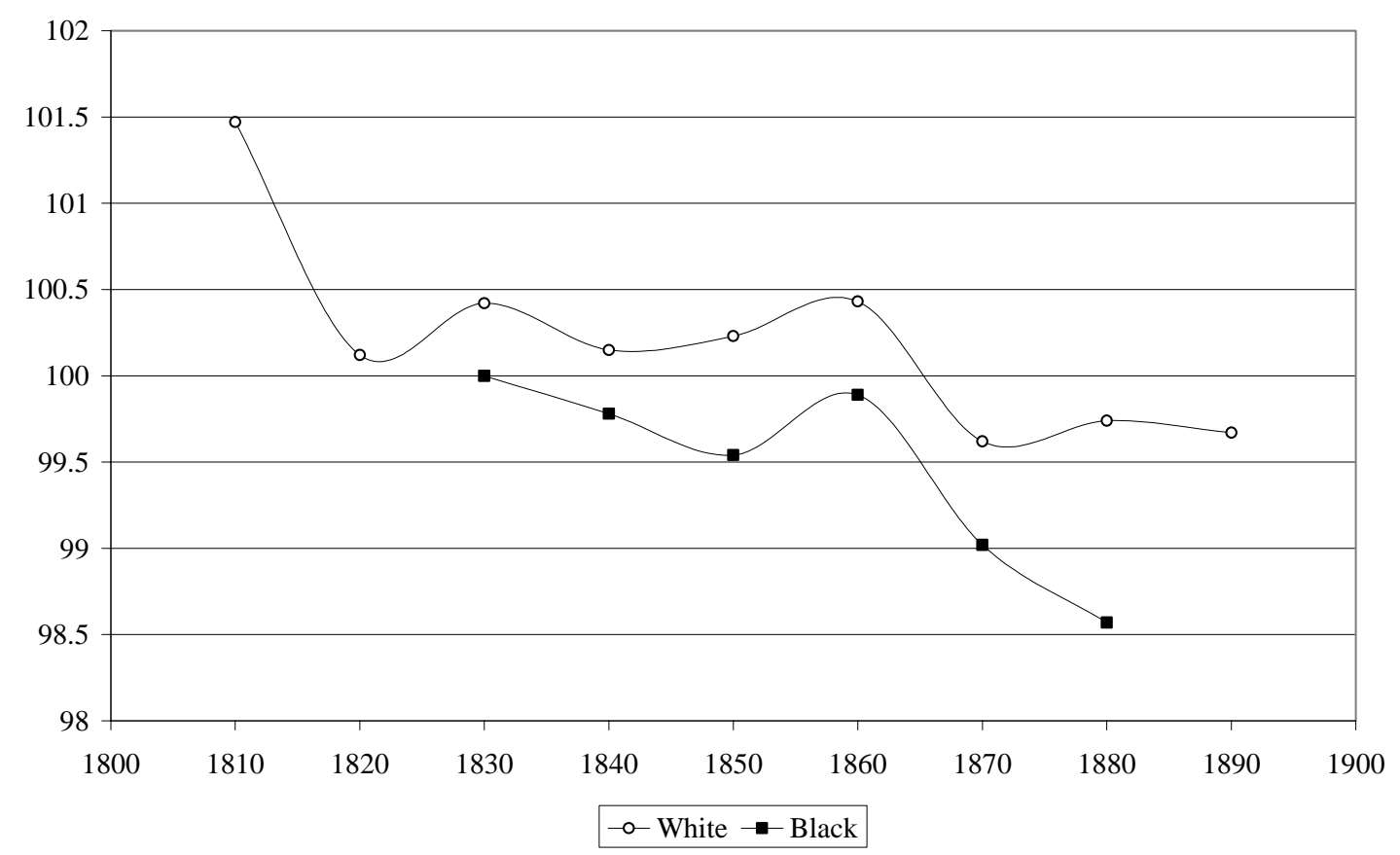

To more rigorously identify these demographic and chronological height differentials, we estimate simple regression models for height as a function of race, birth cohort, region of birth, proximity to water, farm residence, and southern county residence. Means for the regression data sets, for blacks and whites and adults and youth separately, are presented in Table 3. The overall average height difference between blacks and whites is about 1.6 centimeters for adults and 1.2 centimeters for youth. In both groups, the black sample is disproportionately concentrated in the shorter (post-Civil War) birth cohorts, and blacks are less likely to be farm residents but more likely to live close to water. All of these factors could contribute to the overall black-white height gap. However, the coefficients on "black” in the race-pooled regression results in Tables 4 and 
5 indicate that essentially all of the average race gap remains after we control for these characteristics.

Table 3: Means of Regression Data Sets

\begin{tabular}{|c|c|c|c|c|}
\hline & \multicolumn{2}{|c|}{ Adult } & \multicolumn{2}{|c|}{ Youth } \\
\hline & White & Black & White & Black \\
\hline Height (centimeters) & 172.241 & 170.667 & 170.809 & 169.597 \\
\hline \multicolumn{5}{|l|}{ Birth Cohort: } \\
\hline 1780 & .002 & .001 & & \\
\hline 1790 & .009 & .004 & & \\
\hline 1800 & .024 & .009 & & \\
\hline 1810 & .045 & .022 & .026 & .016 \\
\hline 1820 & .050 & .034 & .038 & .016 \\
\hline 1830 & .071 & .046 & .061 & .029 \\
\hline 1840 & .126 & .092 & .098 & .080 \\
\hline 1850 & .206 & .170 & .164 & .123 \\
\hline 1860 & .240 & .238 & .235 & .190 \\
\hline 1870 & .175 & .257 & .298 & .379 \\
\hline 1880 & .053 & .128 & .073 & .150 \\
\hline 1890 & & & .007 & .018 \\
\hline \multicolumn{5}{|l|}{ Region of Birth } \\
\hline New England & .035 & .009 & .026 & .009 \\
\hline Mid-Atlantic & .236 & .094 & .197 & .072 \\
\hline Plains & .017 & .024 & .021 & .020 \\
\hline South East & .118 & .530 & .088 & .397 \\
\hline Great Lakes & .065 & .030 & .068 & .043 \\
\hline Ohio & .514 & .279 & .587 & .420 \\
\hline West & .014 & .034 & .013 & .041 \\
\hline Lake & .143 & .129 & .147 & .086 \\
\hline River & .306 & .473 & .302 & .449 \\
\hline Farm & .166 & .106 & .173 & .104 \\
\hline Southern County & .261 & .338 & .261 & .350 \\
\hline \multicolumn{5}{|l|}{ Age } \\
\hline 14 & & & .003 & .011 \\
\hline 15 & & & .011 & .016 \\
\hline 16 & & & .037 & .045 \\
\hline 17 & & & .090 & .093 \\
\hline 18 & & & .124 & .132 \\
\hline 19 & & & .157 & .152 \\
\hline 20 & & & .157 & .150 \\
\hline 21 & & & .200 & .192 \\
\hline 22 & & & .220 & .211 \\
\hline $\mathrm{N}$ & 17337 & 3520 & 7152 & 1551 \\
\hline
\end{tabular}

For adults, “1880” birth cohort includes those born in the 1880s and 1890s. 
The general decline in height over the course of the 1800s is apparent in all of the adult regressions presented in Table 4 - for the overall sample, and for whites and blacks separately. (The set of birth cohort controls is statistically significant as a group at the .01 level in each regression.) The advantage of farm residence and the disadvantage of proximity to water are also apparent in all of these results. Examining separate regressions for blacks and whites, however, does allow us to identify some differences in the patterns, particularly the advantage held by whites born in the Southeast. These race separate regressions also allow us to more closely examine change in height over time for blacks and whites , controlling for other factors. Figure 6 plots the birth cohort coefficients from these regressions. Here, the decline in height through the first half of the century appears more pronounced for blacks, with a particularly large disadvantage for blacks born in the 1840s. 
Table 4: Height Regressions: Adults

\begin{tabular}{|c|c|c|c|c|c|c|}
\hline & \multicolumn{2}{|c|}{ All } & \multicolumn{2}{|c|}{ White } & \multicolumn{2}{|c|}{ Black } \\
\hline & (Coeff) & (P-value) & (Coeff) & (P-value) & (Coeff) & (P-value) \\
\hline Intercept & 172.074 & .01 & 171.973 & .01 & 171.164 & .01 \\
\hline Black & -1.615 & .01 & & & & \\
\hline \multicolumn{7}{|l|}{ Birth Cohort: } \\
\hline 1780 & 0.812 & .47 & 0.664 & .58 & 1.709 & .57 \\
\hline 1790 & 3.062 & .01 & 2.934 & .01 & 4.686 & .01 \\
\hline 1800 & 1.785 & .01 & 1.769 & .01 & 2.109 & .08 \\
\hline 1810 & 1.943 & .01 & 1.944 & .01 & 2.102 & .01 \\
\hline 1820 & 1.670 & .01 & 1.791 & .01 & 0.851 & .20 \\
\hline 1830 & 1.095 & .01 & 1.219 & .01 & 0.214 & .71 \\
\hline 1840 & 0.318 & .04 & 0.525 & .01 & -1.044 & .02 \\
\hline 1850 & 0.006 & .96 & 0.013 & .93 & 0.043 & .90 \\
\hline 1860 & \multicolumn{2}{|c|}{ Base } & \multicolumn{2}{|c|}{ Base } & \multicolumn{2}{|c|}{ Base } \\
\hline 1870 & -0.193 & .16 & -0.311 & .04 & 0.150 & .64 \\
\hline $1880-90$ & -.0 .149 & .45 & -0.040 & .86 & -0.393 & .32 \\
\hline \multicolumn{7}{|l|}{ Region of Birth } \\
\hline New England & -0.677 & .01 & -0.702 & .01 & 0.452 & .71 \\
\hline Mid-Atlantic & -1.095 & .01 & -1.081 & .01 & -1.307 & .01 \\
\hline Plains & -0.282 & .40 & -0.305 & .41 & -0.407 & .59 \\
\hline South East & 0.314 & .02 & 0.622 & .01 & -0.306 & .25 \\
\hline Great Lakes & -0.276 & .15 & -0.227 & .26 & -0.521 & .45 \\
\hline Ohio & \multicolumn{2}{|c|}{ Base } & \multicolumn{2}{|c|}{ Base } & \multicolumn{2}{|c|}{ Base } \\
\hline West & 0.853 & .01 & 0.935 & .02 & 0.266 & .69 \\
\hline Lake & -0.655 & .01 & -0.599 & .01 & -0.907 & .02 \\
\hline River & -0.350 & .01 & -0.316 & .01 & -0.585 & .04 \\
\hline Farm & 1.374 & .01 & 1.374 & .01 & 1.224 & .01 \\
\hline $\begin{array}{l}\text { Southern } \\
\text { County }\end{array}$ & 0.297 & .01 & 0.350 & .01 & 0.111 & .69 \\
\hline $\mathrm{N}$ & \multicolumn{2}{|c|}{20857} & \multicolumn{2}{|c|}{17337} & \multicolumn{2}{|c|}{3520} \\
\hline Adj. $\mathrm{R}^{2}$ & \multicolumn{2}{|c|}{.03} & \multicolumn{2}{|c|}{.03} & \multicolumn{2}{|c|}{.01} \\
\hline
\end{tabular}


Figure 6: Coefficients on Birth Cohort, Adults (1860 Base)

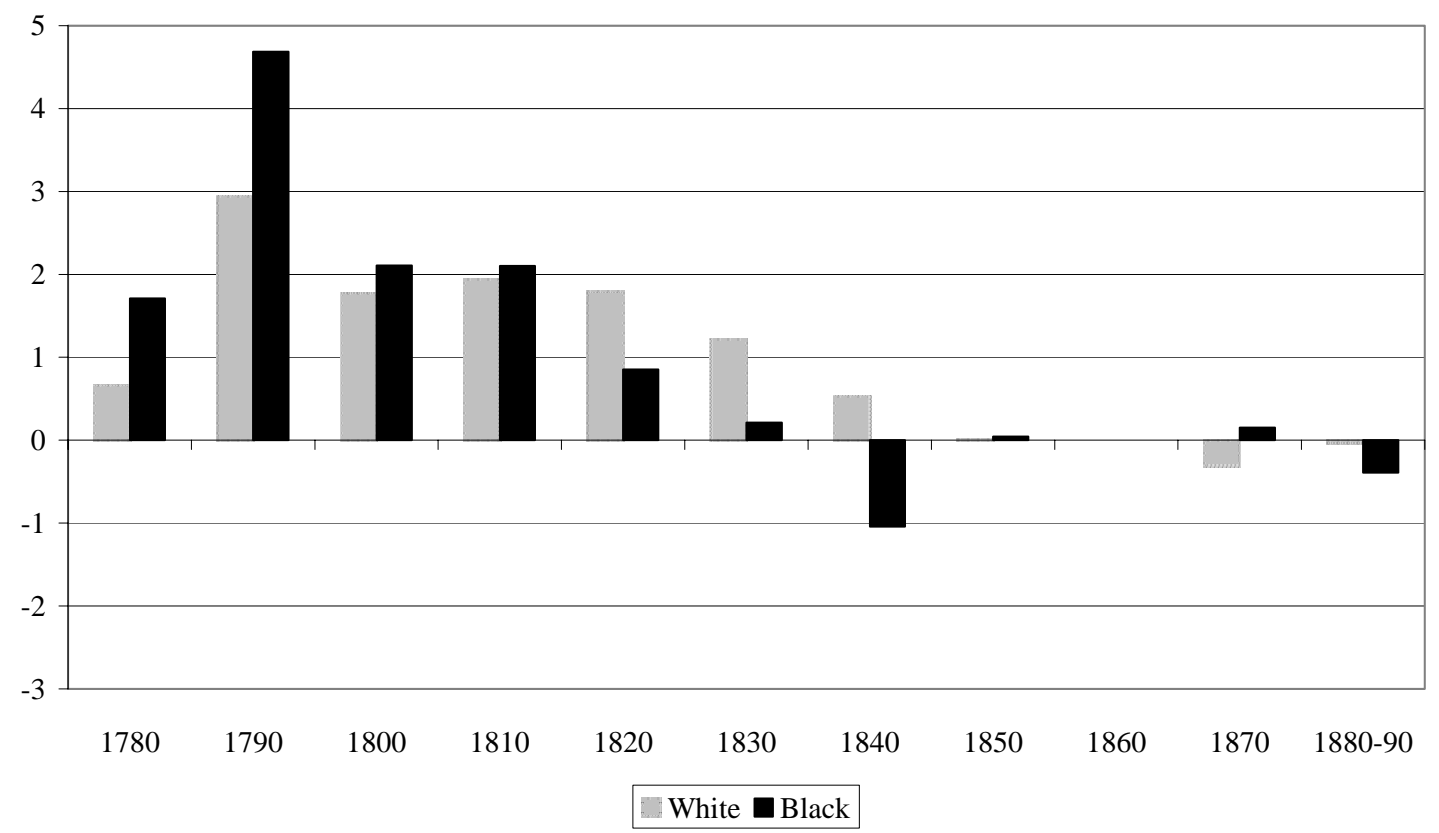

In the youth regressions, we again find advantages from farm residence, disadvantages from proximity to water (except in the black-only regression), a large advantage from Southeastern birth for whites, and no such advantage for Southeasternborn blacks (relative to other blacks). The timing of height decline appears to have been somewhat different for these adolescents than for adults, with more of the decline occurring among post-Civil War birth cohorts (see Figure 7). (The set of birth cohort controls is statistically significant at the .05 level in all of these regressions.) Again, as among adults, the changes over time were somewhat more pronounced for blacks than for whites, at least in these point estimates. 
Table 5: Height Regressions: Youth

\begin{tabular}{|c|c|c|c|c|c|c|}
\hline & \multicolumn{2}{|c|}{ All } & \multicolumn{2}{|c|}{ White } & \multicolumn{2}{|c|}{ Black } \\
\hline & (Coeff) & (P-value) & (Coeff) & (P-value) & (Coeff) & (P-value) \\
\hline Intercept & 172.649 & .01 & 172.569 & .01 & 171.799 & .01 \\
\hline Black & -1.337 & .01 & & & & \\
\hline \multicolumn{7}{|l|}{ Birth Cohort } \\
\hline 1810 & 0.584 & .22 & 0.582 & .24 & 0.250 & .86 \\
\hline 1820 & -0.490 & .23 & -0.536 & .20 & -0.021 & .99 \\
\hline 1830 & -0.220 & .50 & -0.312 & .36 & 0.911 & .40 \\
\hline 1840 & -0.413 & .119 & -0.314 & .27 & -1.207 & .10 \\
\hline 1850 & -0.679 & .01 & -0.596 & .01 & -0.998 & .12 \\
\hline 1860 & \multicolumn{2}{|c|}{ Base } & \multicolumn{2}{|c|}{ Base } & \multicolumn{2}{|c|}{ Base } \\
\hline 1870 & -1.124 & .01 & -1.099 & .01 & -1.399 & .01 \\
\hline 1880 & -1.306 & .01 & -1.139 & .01 & -1.946 & .01 \\
\hline 1890 & -0.500 & .49 & -0.733 & .41 & -0.075 & .96 \\
\hline \multicolumn{7}{|l|}{ Region of Birth } \\
\hline New England & -0.722 & .12 & -0.580 & .22 & -2.255 & .21 \\
\hline Mid-Atlantic & -0.958 & .01 & -0.977 & .01 & -0.338 & .63 \\
\hline Plains & -0.121 & .80 & -0.135 & .79 & -0.146 & .91 \\
\hline South East & 0.468 & .03 & 1.053 & .01 & -0.374 & .33 \\
\hline Great Lakes & -0.253 & .38 & -0.225 & .46 & -0.581 & .50 \\
\hline Ohio & \multicolumn{2}{|c|}{ Base } & \multicolumn{2}{|c|}{ Base } & \multicolumn{2}{|c|}{ Base } \\
\hline West & 0.961 & .07 & 0.404 & .54 & 2.027 & .04 \\
\hline Lake & -0.329 & .13 & -0.302 & .18 & -0.457 & .49 \\
\hline River & -0.454 & .01 & -0.522 & .01 & -0.105 & .80 \\
\hline Farm & 1.545 & .01 & 1.566 & .01 & 1.085 & .08 \\
\hline $\begin{array}{l}\text { Southern } \\
\text { County }\end{array}$ & 0.326 & .08 & 0.302 & .15 & 0.437 & .29 \\
\hline \multicolumn{7}{|l|}{ Age } \\
\hline 14 & -10.861 & .01 & -11.408 & .01 & -10.161 & .01 \\
\hline 15 & -7.481 & .01 & -7.901 & .01 & -6.307 & .01 \\
\hline 16 & -4.513 & .01 & -4.679 & .01 & -3.832 & .01 \\
\hline 17 & -2.584 & .01 & -2.469 & .01 & -3.013 & .01 \\
\hline 18 & -2.043 & .01 & -1.934 & .01 & -2.447 & .01 \\
\hline 19 & -0.684 & .01 & -0.554 & .02 & -1.339 & .02 \\
\hline 20 & -0.631 & .01 & -0.695 & .01 & -0.313 & .59 \\
\hline 21 & 0.055 & .793 & 0.039 & .86 & 0.035 & .95 \\
\hline 22 & \multicolumn{2}{|c|}{ Base } & \multicolumn{2}{|c|}{ Base } & \multicolumn{2}{|c|}{ Base } \\
\hline $\mathrm{N}$ & \multicolumn{2}{|c|}{8703} & \multicolumn{2}{|c|}{7152} & \multicolumn{2}{|c|}{1551} \\
\hline Adj. $R^{2}$ & \multicolumn{2}{|c|}{.08} & \multicolumn{2}{|c|}{.07} & \multicolumn{2}{|c|}{.07} \\
\hline
\end{tabular}


Figure 7: Coefficients on Birth Cohort, Youth (1860 Base)

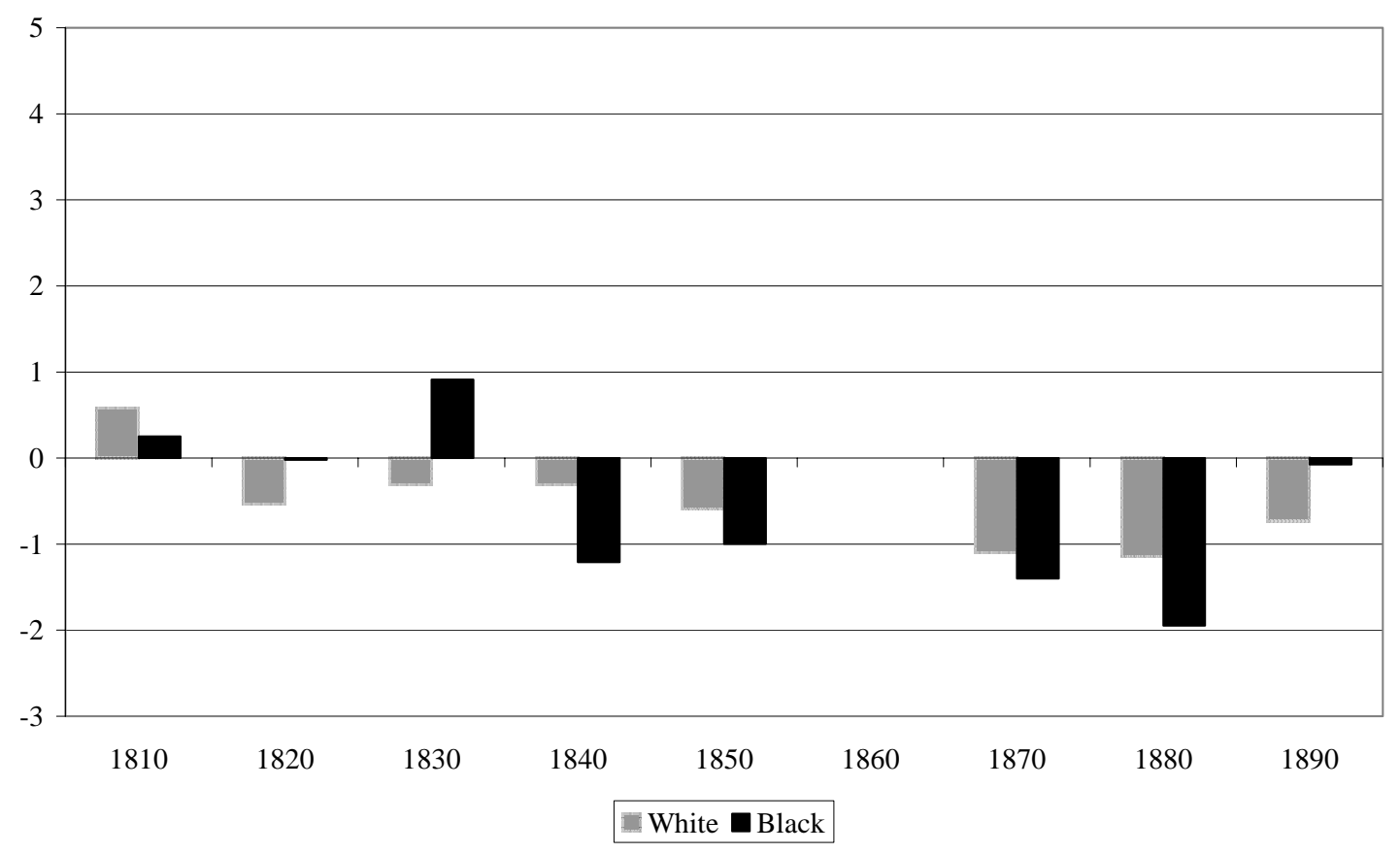

$\underline{\text { Conclusion }}$

Our data on nearly a century of inmate records from the Ohio state prison provide a rare opportunity to examine the heights of free, Northern-resident blacks in the 1800s and to compare their heights to those of whites measured at the same time for the same purposes. Our results indicate that the average heights of African American residents of Ohio declined just as the average heights of white residents of Ohio did. The negative biological consequences of the initial expansion of industrialization and trade affected these two groups in similar ways, despite the substantial differences in their places of origin and other conditions of their lives. We also find that the height advantage of Southern birth was quite apparent for whites but did not extend to blacks. Any general benefits from the warmer climate and more rural conditions of a Southern childhood were, not surprisingly, overwhelmed by the profound biological challenges of slave life. 
Finally, while modern Africans and Europeans achieve comparable average height when brought to maturity under optimal biological conditions, we find that, controlling for many relevant factors, substantial and statistically significant height differences persisted between whites and blacks in Ohio in the 1800s. 


\section{$\underline{\text { References }}$}

Bertaux, N., 1993, “Structural Economic Change and Occupational Decline among Black Workers in Nineteenth-Century Cincinnati,” in Taylor, ed., Race and the City: Work, Community, and Protest in Cincinnati, 1820-1970. Urbana: University of Illinois Press, p. 126-155.

Bodenhorn, Howard, 1999, “A Troublesome Caste: Height and Nutrition of Antebellum Virginia’s Rural Free Blacks,” Journal of Economic History 59, 972-96.

Cayton, A. R. L., 2002, Ohio: The History of a People. Columbus: Ohio State University Press.

Cuff, T., 2005, The Hidden Cost of Economic Development: The Biological Standard of Living in Antebellum Pennsylvania. Vermont: Ashgate.

Eveleth, P.B. and J.M. Tanner, 1976, Worldwide Variation in Human Growth. Cambridge: Cambridge University Press.

Floud, R., Wachter, K. and A. Gregory, 1990, Height, Health and History: Nutritional Status in the United Kingdom, 1750-1980. Cambridge: Cambridge University Press.

Gerber, D. A., 1976, Black Ohio and the Color Line 1860-1915. Urbana: University of Illinois Press.

Johnson, Daniel M., and Rex R. Campbell, 1981, Black Migration in America: A Social Demographic History. Durham: Duke University Press.

Komlos, J., 1987, “The Height and Weight of West Point Cadets: Dietary Change in Antebellum America.” Journal of Economic History 47, 897-927. 
Komlos, J., 1992, “Toward an Anthropometric History of African-Americans: The Case of Free Blacks in Antebellum Maryland,” in Goldin and Rockoff, eds., Strategic Factors in $19^{\text {th }}$ Century American Economic History. Chicago: University of Chicago Press, 1992, p. 297-329.

Komlos, J., 1996, “On Anomalies in Economic History: Reflections on the Antebellum Puzzle.” Journal of Economic History 56, 202-214.

Komlos, J., 1998, “Shrinking in a Growing Economy? The Mystery of Physical Stature during the Industrial Revolution.” Journal of Economic History 58, 779-802. Komlos, J., Coclanis, P., 1997, “On the Puzzling Cycle in the Biological Standard of Living: The Case of Antebellum Georgia.” Explorations in Economic History 34, 433-59.

Steckel, R.H., 1986, “A Peculiar Population: The Nutrution, Health, and Mortality of American Slaves from Childhood to Maturity,” Journal of Economic History 46, 721-42.

Steckel R.H., 1992a, "Stature and Living Standards in the United States,” in Gallman and Wallis, eds., American Economic Growth and Standards of Living Before the Civil War. Chicago, University of Chicago Press.

Steckel, R.H., 1995, “Stature and the Standard of Living.” Journal of Economic Literature 33, 1903-1940.

Steckel, R.H. and D. Haurin, 1994, "Health and Nutrition in the American Midwest: Evidence from the Height of Ohio National Guardsman 1850-1910.” In: Komlos, J. (Ed.), Stature, Living Standards and Economic Development. University Press of Chicago, Chicago, pp. 117-128. 
Taylor, Henry Louis, Jr., 1993, “City Building, Public Policy, the Rise of the Industrial City, and Black Ghetto Slum Formation in Cincinnati, 1850-1940,” in Taylor, ed., $\underline{\text { Race and the City: Work, Community, and Protest in Cincinnati, 1820-1970. }}$ Urbana: University of Illinois Press, p. 156-192. 


\section{CESifo Working Paper Series}

(for full list see www.cesifo-group.de)

1713 Marc-Andreas Muendler and Sascha O. Becker, Margins of Multinational Labor Substitution, May 2006

1714 Surajeet Chakravarty and W. Bentley MacLeod, Construction Contracts (or "How to Get the Right Building at the Right Price?”), May 2006

1715 David Encaoua and Yassine Lefouili, Choosing Intellectual Protection: Imitation, Patent Strength and Licensing, May 2006

1716 Chris van Klaveren, Bernard van Praag and Henriette Maassen van den Brink, Empirical Estimation Results of a Collective Household Time Allocation Model, May 2006

1717 Paul De Grauwe and Agnieszka Markiewicz, Learning to Forecast the Exchange Rate: Two Competing Approaches, May 2006

1718 Sijbren Cnossen, Tobacco Taxation in the European Union, May 2006

1719 Marcel Gérard and Fernando Ruiz, Interjurisdictional Competition for Higher Education and Firms, May 2006

1720 Ronald McKinnon and Gunther Schnabl, China's Exchange Rate and International Adjustment in Wages, Prices, and Interest Rates: Japan Déjà Vu?, May 2006

1721 Paolo M. Panteghini, The Capital Structure of Multinational Companies under Tax Competition, May 2006

1722 Johannes Becker, Clemens Fuest and Thomas Hemmelgarn, Corporate Tax Reform and Foreign Direct Investment in Germany - Evidence from Firm-Level Data, May 2006

1723 Christian Kleiber, Martin Sexauer and Klaus Waelde, Bequests, Taxation and the Distribution of Wealth in a General Equilibrium Model, May 2006

1724 Axel Dreher and Jan-Egbert Sturm, Do IMF and World Bank Influence Voting in the UN General Assembly?, May 2006

1725 Swapan K. Bhattacharya and Biswa N. Bhattacharyay, Prospects of Regional Cooperation in Trade, Investment and Finance in Asia: An Empirical Analysis on BIMSTEC Countries and Japan, May 2006

1726 Philippe Choné and Laurent Linnemer, Assessing Horizontal Mergers under Uncertain Efficiency Gains, May 2006

1727 Daniel Houser and Thomas Stratmann, Selling Favors in the Lab: Experiments on Campaign Finance Reform, May 2006 
1728 E. Maarten Bosker, Steven Brakman, Harry Garretsen and Marc Schramm, A Century of Shocks: The Evolution of the German City Size Distribution 1925 - 1999, May 2006

1729 Clive Bell and Hans Gersbach, Growth and Enduring Epidemic Diseases, May 2006

1730 W. Bentley MacLeod, Reputations, Relationships and the Enforcement of Incomplete Contracts, May 2006

1731 Jan K. Brueckner and Ricardo Flores-Fillol, Airline Schedule Competition: ProductQuality Choice in a Duopoly Model, May 2006

1732 Kerstin Bernoth and Guntram B. Wolff, Fool the Markets? Creative Accounting, Fiscal Transparency and Sovereign Risk Premia, May 2006

1733 Emmanuelle Auriol and Pierre M. Picard, Government Outsourcing: Public Contracting with Private Monopoly, May 2006

1734 Guglielmo Maria Caporale and Luis A. Gil-Alana, Modelling Structural Breaks in the US, UK and Japanese Unemployment Rates, May 2006

1735 Emily J. Blanchard, Reevaluating the Role of Trade Agreements: Does Investment Globalization Make the WTO Obsolete?, May 2006

1736 Per Engström and Bertil Holmlund, Tax Evasion and Self-Employment in a High-Tax Country: Evidence from Sweden, May 2006

1737 Erkki Koskela and Mikko Puhakka, Cycles and Indeterminacy in Overlapping Generations Economies with Stone-Geary Preferences, May 2006

1738 Saku Aura and Thomas Davidoff, Supply Constraints and Housing Prices, May 2006

1739 Balázs Égert and Ronald MacDonald, Monetary Transmission Mechanism in Transition Economies: Surveying the Surveyable, June 2006

1740 Ben J. Heijdra and Ward E. Romp, Ageing and Growth in the Small Open Economy, June 2006

1741 Robert Fenge and Volker Meier, Subsidies for Wages and Infrastructure: How to Restrain Undesired Immigration, June 2006

1742 Robert S. Chirinko and Debdulal Mallick, The Elasticity of Derived Demand, Factor Substitution and Product Demand: Corrections to Hicks' Formula and Marshall's Four Rules, June 2006

1743 Harry P. Bowen, Haris Munandar and Jean-Marie Viaene, Evidence and Implications of Zipf's Law for Integrated Economies, June 2006

1744 Markku Lanne and Helmut Luetkepohl, Identifying Monetary Policy Shocks via Changes in Volatility, June 2006 
1745 Timo Trimborn, Karl-Josef Koch and Thomas M. Steger, Multi-Dimensional Transitional Dynamics: A Simple Numberical Procedure, June 2006

1746 Vivek H. Dehejia and Yiagadeesen Samy, Labor Standards and Economic Integration in the European Union: An Empirical Analysis, June 2006

1747 Carlo Altavilla and Paul De Grauwe, Forecasting and Combining Competing Models of Exchange Rate Determination, June 2006

1748 Olaf Posch and Klaus Waelde, Natural Volatility, Welfare and Taxation, June 2006

1749 Christian Holzner, Volker Meier and Martin Werding, Workfare, Monitoring, and Efficiency Wages, June 2006

1750 Steven Brakman, Harry Garretsen and Charles van Marrewijk, Agglomeration and Aid, June 2006

1751 Robert Fenge and Jakob von Weizsäcker, Mixing Bismarck and Child Pension Systems: An Optimum Taxation Approach, June 2006

1752 Helge Berger and Michael Neugart, Labor Courts, Nomination Bias, and Unemployment in Germany, June 2006

1753 Chris van Klaveren, Bernard van Praag and Henriette Maassen van den Brink, A Collective Household Model of Time Allocation - a Comparison of Native Dutch and Immigrant Households in the Netherlands, June 2006

1754 Marko Koethenbuerger, Ex-Post Redistribution in a Federation: Implications for Corrective Policy, July 2006

1755 Axel Dreher, Jan-Egbert Sturm and Heinrich Ursprung, The Impact of Globalization on the Composition of Government Expenditures: Evidence from Panel Data, July 2006

1756 Richard Schmidtke, Private Provision of a Complementary Public Good, July 2006

1757 J. Atsu Amegashie, Intentions and Social Interactions, July 2006

1758 Alessandro Balestrino, Tax Avoidance, Endogenous Social Norms, and the Comparison Income Effect, July 2006

1759 Øystein Thøgersen, Intergenerational Risk Sharing by Means of Pay-as-you-go Programs - an Investigation of Alternative Mechanisms, July 2006

1760 Pascalis Raimondos-Møller and Alan D. Woodland, Steepest Ascent Tariff Reforms, July 2006

1761 Ronald MacDonald and Cezary Wojcik, Catching-up, Inflation Differentials and Credit Booms in a Heterogeneous Monetary Union: Some Implications for EMU and new EU Member States, July 2006 
1762 Robert Dur, Status-Seeking in Criminal Subcultures and the Double Dividend of ZeroTolerance, July 2006

1763 Christa Hainz, Business Groups in Emerging Markets - Financial Control and Sequential Investment, July 2006

1764 Didier Laussel and Raymond Riezman, Fixed Transport Costs and International Trade, July 2006

1765 Rafael Lalive, How do Extended Benefits Affect Unemployment Duration? A Regression Discontinuity Approach, July 2006

1766 Eric Hillebrand, Gunther Schnabl and Yasemin Ulu, Japanese Foreign Exchange Intervention and the Yen/Dollar Exchange Rate: A Simultaneous Equations Approach Using Realized Volatility, July 2006

1767 Carsten Hefeker, EMU Enlargement, Policy Uncertainty and Economic Reforms, July 2006

1768 Giovanni Facchini and Anna Maria Mayda, Individual Attitudes towards Immigrants: Welfare-State Determinants across Countries, July 2006

1769 Maarten Bosker and Harry Garretsen, Geography Rules Too! Economic Development and the Geography of Institutions, July 2006

1770 M. Hashem Pesaran and Allan Timmermann, Testing Dependence among Serially Correlated Multi-category Variables, July 2006

1771 Juergen von Hagen and Haiping Zhang, Financial Liberalization in a Small Open Economy, August 2006

1772 Alessandro Cigno, Is there a Social Security Tax Wedge?, August 2006

1773 Peter Egger, Simon Loretz, Michael Pfaffermayr and Hannes Winner, Corporate Taxation and Multinational Activity, August 2006

1774 Jeremy S.S. Edwards, Wolfgang Eggert and Alfons J. Weichenrieder, The Measurement of Firm Ownership and its Effect on Managerial Pay, August 2006

1775 Scott Alan Carson and Thomas N. Maloney, Living Standards in Black and White: Evidence from the Heights of Ohio Prison Inmates, 1829 - 1913, August 2006 